\title{
Chris Berry
}

\section{The Poll Provisions and Local Government Reform in Western}

Australia

Preface

Local government reform is on the agenda of many countries, particularly those with local government systems based on the Anglo-Saxon approach. In many of these jurisdictions, from Wales to the Republic of Ireland, to most of the Australian states and New Zealand, the dominant reform narrative is structural change, and the challenge faced in most of these jurisdictions is how to marry the apparent national interest in creating bigger councils with the desire of citizens to have a say about how their towns and districts are governed; it is a debate that inevitably finds governments' technical experts at odds with local citizens. The resulting challenge has led to a range of new approaches to structural reform, optimistically designed to meet the needs of both.

Since completing a Doctor of Philosophy on local government boundaries, Chris Berry has spent nearly 30 years working in the Western Australian local government sector, and now consults to local governments in Western Australia.
One of the most hotly contested issues is the role of local referenda. For much of the last 150 years a fundamental tenet of local government law in New Zealand has been the right of residents to decide the future of their locality through a binding referendum. Indeed, for the second half of the 20th century this was a defining difference between Labour and National governments, with Labour governments looking to weaken the referenda requirements in order to promote consolidation and National governments focused on retaining them. Today the roles are reversed, but the issue is as topical as ever, with the local government sector recently asking for binding referenda to be reinstated.

Given the issue's currency, this article from Chris Berry provides an insight into how the right to hold referenda has had an impact on local government reform in Western Australia - lessons that should be helpful given the content of the Local Government Act 2002 Amendment Bill which is currently with 
the Local Government and Environment Committee.

Mike Reid and Michael Macaulay, Guest Editors

\section{Introduction}

The local government system in Western Australia has two unique characteristics. It is the only state in Australia where there has not been significant reform of the sector. In addition, it is the only state where legislation contains binding provisions for a poll of electors on local government amalgamations. It would be reasonable to conclude that these two characteristics are linked.

Referenda - the holding of a direct vote on a specific issue - are in common use around the world at every level of government, with the June 2016 Brexit poll being a well-known example. A distinction might be made between mandatory referenda, such as those provided for under certain circumstances in Western Australia's Local Government Act 1995, with conditions to be met for a binding result, and optional referenda, initiated by local government, which are non-binding and indicative, possibly assisting local government decision making. Further, reference might be made to the 'popular referendum', where the means is provided for a petition signed by a certain minimum number of registered voters to force a public vote, a form of direct democracy (Wikipedia, 2016; ACE, 2016).

Although Western Australia is the only state in Australia with legislation provisions governing a binding elector's poll on local government amalgamations, there are poll provisions in place in New Zealand (Local Government Act 2002, schedule 3) and in some parts of Canada (such as in British Columbia: Local Government Act 1996, s8). This article looks at the history and effect of the poll provisions in Western Australia, and considers the question as to whether the poll provisions have impeded structural reform of the local government sector in the state.

\section{Background}

The current poll provisions of the Western Australia Local Government Act
1995 can be triggered by a petition signed by at least 250 individual electors or $10 \%$ of total electors (whichever is the lesser) of a district affected by an amalgamation proposal. ${ }^{1}$ The results are binding, and the proposed amalgamation is defeated if a poll is held and at least $50 \%$ of the electors of one of the districts vote in the poll and a majority of those voting oppose the amalgamation.

The 1995 act provisions replaced and amended provisions that were first introduced through the Local Government Act Amendment Act (No. 4) 1975. Under the 1975 amendments, provision was made for the presentation who vote thereat is not less than onethird of the number entitled to vote thereat and a majority of the valid votes recorded at the poll are against the proposal, the Minister shall not present the petition containing it to the Governor.

The timing - 1975 - of this amendment to the Local Government Act 1960 is significant, as it followed on from several major boundary inquiries, including a royal commission on metropolitan boundaries which reported in 1975. These reports recommended that the number of metropolitan local

\section{The current poll provisions of the Western Australia Local Government Act 1995 can be triggered by a petition signed by at least 250 individual electors or $10 \%$ of total electors (whichever is the lesser) of a district affected by an amalgamation proposal.}

of a petition where the adjustment of municipal boundaries, the abolition of a municipal district or the union of two or more adjoining municipalities was proposed. Unless councils had jointly signed the petition, it was mandatory for ratepayers of each affected district to be given the opportunity to demand a referendum on the proposals, and only one third of the electorate were required to turn out to vote to create a binding outcome (Department of Local Government, 1976, p.21). Specifically, section $30 \mathrm{~A}$ of Local Government Act 1960-1975 provided that:

4) at least fifty per centum of the number of electors of a municipality which will be directly affected ... or fifty of them, whichever is the lesser number, can demand that the proposal be put to a poll. ...

(6) (e) if at the poll in any municipality the number of electors governments be reduced from 28 (in $1968)$ to 17,18 or 22 respectively. The proposed implementation of the royal commission recommendations by the then government was a direct threat to the future of the smaller local governments in the metropolitan area, including the inner urban City of Subiaco (1976 population: $16,100)$. While the city would continue as a local government entity under the royal commission recommendations, a significant portion (known locally as the Crawley Corridor) was proposed to be ceded to the neighbouring City of Nedlands.

A subsequent amendment to the 1960 act (section 30A) became known as the 'Dadour amendment.' 2 The MP for Subiaco, Tom Dadour, who was also a sitting Subiaco councillor, had previously called for an amendment to the Local Government Act in a speech to Parliament in 1973, arguing that boundary changes should only be made after a poll of 
residents. Dadour continued to lobby vigorously on this proposal, including to the new premier after the 1974 state election, his efforts culminating in what became known as the Dadour Bill being presented to Parliament in early 1975. It provided for 50 or more ratepayers to demand a poll on a boundary change, and required one third of eligible voters to vote, with a simple majority voting 'no' to defeat the proposal (Spillman, 1985, p.332). The proposed amendment was opposed by the Labor opposition of the time. The provisions were seen as diminishing ministerial responsibility, 'tak[ing] away from the Minister the right that all Ministers for Local Government have had up to the present. It seeks to take away that power for no good reason, and it does appear to take some of the control from the Government in exercising responsibilities
Town and Shire of Albany had been mooted for some time. A community group known as the Albany One Movement submitted a petition for their amalgamation to the Local Government Boundaries Commission in 1989. The commission subsequently recommended the creation of a local government based on the urban areas of the town and shire. A poll involving both town and shire electors defeated the proposal (Department of Local Government, 1987). ${ }^{3}$

The only amalgamation to occur after the Dadour amendment (and prior to the 1995 version of the legislation) was the creation of the City of KalgoorlieBoulder in 1989. As both the Town of Kalgoorlie and Shire of Boulder agreed to the merger by council resolution on the same date (14 November 1988) and a jointly signed petition was forwarded

\section{The evidence shows that most electors, or at least those electors who care enough to turn out to vote on such occasions, do not support amalgamations.}

of government' (Legislative Assembly of Western Australia, 1975, p.1249).

When the City of Nedlands followed up the royal commission recommendation with a petition for boundary change in October 1975, hundreds of Subiaco ratepayers supported the demand for a poll via counter petition. Following an extensive city campaign leading up to the March 1976 referendum, nearly 60\% of Subiaco electors turned out to vote, with $94.4 \%$ voting 'no' to the proposed boundary change. The poll provisions had had their first success in blocking a local government boundary change.

After the Subiaco referendum the poll provisions were used in a number of other areas, and each time the proposed boundary change was stopped. For example, the amalgamation of the 'doughnut' local governments of the to the governor (Department of Local Government, 1992, p.3), no poll was required.

\section{A new Local Government Act}

After a comprehensive review and consultation process, the new Local Government Act 1995 came into effect on 1 July 1996 (Department of Local Government, 1996, p.8). A new process for local government boundary change was established, with a Local Government Advisory Board replacing the former Local Government Boundaries Commission. Any proposal for boundary change or amalgamation, which could come from the minister, the community or from a local government, must be referred to the board for review. Schedule 2.1 of the act sets out the inquiry process and relevant criteria. While the specifics of the poll provisions were altered, the spirit of the Dadour provisions was retained, but the key numbers were changed (50\% of voters for a binding result rather than one third) to make the process 'more democratic'. Another important change saw the poll provision removed for boundary changes and retained only for amalgamations. This change would have major ramifications when metropolitan boundary changes were being progressed in 2015.

If, on completing an inquiry, the Local Government Advisory Board recommends to the minister that an amalgamation proposal should proceed, the poll provisions come into play. Before the minister can consider any such recommendation, the board must inform affected electors of their right to hold a poll on the proposal. A valid request for a poll must be signed by at least 250 individual electors or $10 \%$ of total electors (whichever is the lesser) of a district. If a poll is held and at least 50\% of the electors of one of the districts vote in the poll and a majority of those voting oppose the amalgamation, the minister must reject the board's recommendation of amalgamation. Under clause 9 of schedule 2.1 of the act, the board is to determine the question to be answered by electors and to prepare a summary case for each way of answering the question.

The government amended the legislation in 1998 'to make it clear that where a poll is requested in relation to a proposed amalgamation of two or more local governments the poll applies only to the local government which has received the request' (Legislative Assembly of Western Australia, 1998, p.2456), effectively changing the application of the poll from 'the districts' to 'that district', even though only one of the districts would have to return a 'no' vote to stop the proposal.

These polls, like many elections, often turn into battles of vested interests, with claims and counter claims often based on emotive arguments rather than hard facts. In most circumstances a referendum must have a $50 \%$ 'yes' vote to carry the proposition, but in the case of these local government amalgamation polls the obverse is true and a $50 \%$ 
turnout and a 50\% 'no' vote is required to stop a proposal. The default position is that the amalgamation will proceed. The parties that oppose a particular amalgamation therefore have to work across the community to ensure they muster enough support to generate the sufficient numbers to defeat the proposal. Perversely, where such polls attract a large number (but not necessarily a majority) of 'yes' voters, such voters increase the likelihood of a binding poll result by their participation. Some of the stakeholders who better understood the provisions have realised that it is better for those in favour of a proposal to not vote to reduce the possibility of a binding poll result.

Polls under the Local Government Act 1995 The poll provisions of the Local Government Act 1995 have been well tested, with 17 polls conducted between 1998 and 2015 (Tables 1-4). These polls have been categorised into three reform eras: the period prior to the 2009 statewide reform process commencing, the period of state-wide reform (2009-13) and the period of metropolitan reform (2013-15).

The evidence shows that most electors, or at least those electors who care enough to turn out to vote on such occasions, do not support amalgamations. Most amalgamation referenda have been defeated, although seven proposals did not attract sufficient turnout to yield a binding result (although the majority of those participating voted 'no'). The likelihood of a binding 'no' vote is greater in the less populous councils. This particularly characterised the polls held prior to the metropolitan reform phase: where the boundary changes were defeated (seven councils), the average electors roll was 1,768 ; where the boundary changes proceeded (five councils) the average electors roll was 8,517. Paradoxically, it might be argued that it is in the smaller local governments, where amalgamation is most required, that amalgamation is more likely to be defeated by a poll, given the lower numbers required to enforce a binding outcome. The more recent metropolitan amalgamation polls of 2015 (Table 4) were undertaken in a different reform context.

Table 1. Amalgamation Poll results, Western Australia 1995-2015

\begin{tabular}{lcccc}
\hline Phase & No. of polls & No. valid polls & $\begin{array}{c}\text { No. where the } \\
\text { amalgamations } \\
\text { defeated }\end{array}$ & $\begin{array}{c}\text { No. where the } \\
\text { amalgamations } \\
\text { proceeded }\end{array}$ \\
\hline $\begin{array}{l}\text { 1. Pre 2009 Reform } \\
\text { initiative }\end{array}$ & 7 & 4 & 4 & 3 \\
$\begin{array}{l}\text { 2. State-wide Reform } \\
\text { period 2009 -2013 }\end{array}$ & 5 & 3 & 3 & 2 \\
$\begin{array}{l}\text { 3. Metropolitan Reform } \\
\text { period 2013 -2015 }\end{array}$ & 5 & 3 & 3 & 0 * \\
TOTAL & 17 & 10 & 10 & 5 \\
\hline
\end{tabular}

*While two polls were not valid, the amalgamation was defeated by valid polls in the other amalgamating local government.

Phase 1: Pre the 2009 reform initiative

The first test for the 1995 act poll provisions was in the Shire of Albany in 1998 (1997 population 13,165), where the poll on the proposed amalgamation with the Town of Albany failed to attract the necessary $50 \%$ voter turnout and the amalgamation into the City of Albany proceeded.

The amalgamation of the urban centre of Geraldton and the 'doughnut' Shire of Greenough in the Mid West region of Western Australia was much more controversial. The Greenough poll, a postal ballot overseen by the Western Australia Electoral Commission, was characterised by an extensive media campaign conducted by the City of Geraldton which included local television advertising and newspaper advertisements. The extraordinary part of the campaign was the unprecedented negative message promoted by the city, based around discouraging Greenough electors from voting to ensure a nonbinding poll result. It included full-page local press advertisements with banner headlines such as: 'Plea for unity don't vote'; 'Let's Grow Together, Let's Grow Today. Greenough ballot, throw it away'; and 'Stronger if we unite. Support unification and put the ballot in the bin'. This campaign was extensively criticised by the local press, and by local electors on both sides of the boundary. As has been noted, an amalgamation poll referendum must have a 50\% turnout and a 50\% 'no' vote to stop a proposal. The outcome of the Greenough poll was convincing on both counts, with nearly 5,000 of the 7,763 ballots returned (74\%), and $90 \%$ of those cast against the merger.
With this conclusive poll outcome, the City of Geraldton and Shire of Greenough continued as separate entities through 1999. The chief executive officer of the City of Geraldton observed that 'the current situation is so unsustainable unification will occur at some time in the future through boundary changes or an amalgamation agreement between the shire and the city'. But he would not be around to see it, as his contract was terminated in April 2000 after just 16 months' tenure..$^{5}$ The mayor did not run at the next council election in October 2001.

It is perhaps not surprising that amalgamation eventually occurred in 2006. Once again there was a petition for a poll of Greenough residents, but without the acrimonious campaign of 1999 fewer than 50\% of the Greenough electors voted, so the poll result was not binding.

In retrospect, the amalgamation of the City of Geraldton and Shire of Greenough to form the City of GeraldtonGreenough could be judged to be a significant success. Community benefits and outcomes included new leadership with a new organisational structure which created capacity to expand the provision of services and improve delivery and standards of existing ones. The new structure incorporated key functions that were lacking in the old entities and applied additional resources to areas that had previously been under-resourced, including tourism and marketing, economic development, environmental sustainability and engagement with community groups (Department of Local Government, 2010). The new entity has 
won significant awards, and as further testimony to that success the adjoining Shire of Mullewa (population 1,000) amalgamated with the City of GeraldtonGreenough in 2011 to form the City of Greater Geraldton (Office of the Minister for Local Government, 2011).

Held on the same day in 1999, a poll of electors of the Shire of Northam had a very similar outcome, with nearly 1,700 of a potential 2,300 ballots cast (74\%), with 95\% against the merger. The poll was conducted by the Shire of Northam, which at the same time was campaigning against amalgamation. This caused concern, as people were uncomfortable
Phase 3: Metropolitan reform 2013-15

On 30 July 2013, following on from the recommendations of the Metropolitan Local Government Review Panel, the state government announced plans to reduce the number of metropolitan local governments from 30 to 14 , as well as to amend the act so that the poll provisions could not be used in metropolitan Perth (Department of Local Government and Communities, 2016). While the local government sector was expecting the government to announce plans for major metropolitan reform, the removal of the long-standing poll provisions was a surprise. The Local Government

\section{The poll provisions of the Western Australia Local Government Act 1995 can and do stop amalgamations, and have done so as recently as 2015 .}

with the primary opponents having a direct role in ensuring that the poll was conducted in a fair and open manner. This situation led to further legislative change relating to the running of polls on amalgamation: the Local Government Act was amended in 2004 to provide for the Western Australia Electoral Commission to be responsible for the conduct of such polls (clause 9(2)). All amalgamation polls since 2004 have been conducted by the Western Australian Electoral Commission.

\section{Phase 2: State-wide reform 2009-13}

In February 2009 a state government agenda for voluntary local government reform was initiated. Funding was offered to local governments to form regional transition groups (RTGs), which were to undertake cost-benefit analyses of the benefits to the community (Berry, 2012). After the business planning process was completed by a number of groups, amalgamation proposals were subsequently defeated in polls in Perenjori, Westonia and Cuballing (Table 3). Amalgamation of the Shire of Mullewa and the City of Geraldton-Greenough took effect on 1 July 2011.
Association president described the poll provisions as the 'safety net for the community' and announced that their arbitrary suspension would be opposed. An opposition MP moved a motion in Parliament to support the retention of the Dadour local poll provision in the Local Government Act in September 2013, leading to a long debate in the chamber about the origins, intentions and effects of the poll provisions (Legislative Assembly of Western Australia, 2013, pp.4365-94).

Despite the political debates, the local government reform process continued. The Local Government Advisory Board subsequently received 38 proposals for amalgamations and boundary changes to districts in metropolitan Perth in October 2013, with 12 proposals from the minister for local government, 25 from local governments and one from electors. After an extensive public consultation process the board submitted its report to the minister in September 2014, with recommendations for amalgamations and boundary adjustments that would reduce Perth's 30 councils to 16 . The key point here is that as well as amalgamations, there are also provisions in the legislation which allow for local governments to be subsumed by a continuing entity though a boundary adjustment, thus not triggering the poll provisions. Some of the proposals received by the board used this approach, and some of the recommendations of the board were also based on this approach, concerned as it was with recommending on the best boundaries rather than on the mechanism of their achievement. This difference in implementation was seen as an inequity, with the opposition spokesperson moving in Parliament:

That this house - (a) condemns the Premier and the Minister for Local Government for allowing, through its forced amalgamation process, some communities in the metropolitan area an opportunity to have a poll under the Dadour provisions in the Local Government Act 1995 about their local council's future, while others have not been given that democratic right; and (b) further, supports all affected communities having a right to a poll on their council's future. (Legislative Assembly of Western Australia, 2014, p.8879)

Some councils had non-binding polls prior to the board concluding its recommendations, including in conjunction with their 2013 postal elections.

The minister subsequently accepted all but two of the report's key boundary recommendations. ${ }^{6}$ On 24 December 2014 governor's orders to change the boundaries of nine local government districts and abolish six local governments were gazetted. Naturally this caused a public outcry, particularly since many communities would not have access to poll provisions to have their say. Three proposed amalgamations, involving six metropolitan councils, were subject to the poll provisions of the act. Petitions for polls were subsequently received for five of the affected local governments, Cockburn, Kwinana, East Fremantle, South Perth and Victoria Park. The Local Government Advisory Board had a role in preparing statements for the 'yes' and 'no' cases for the polls. There were significant community campaigns for the 'no' case, some of which were underpinned by 
significant council resources and some of which were supported by government backbenchers. There was no comparable campaign waged by any party in support of the reforms.

On 7 February 2015 the proposed amalgamations were defeated through valid polls in three of the local governments (Kwinana, East Fremantle and South Perth) (Table 4). With the proposed reforms now in disarray, the state government put its local government reform agenda on hold on 17 February 2015 and governor's orders for boundary adjustments not supported by the councils were revoked (Offices of the Premier and Minister for Local Government).

\section{Review and future directions}

The poll provisions of the Western Australia Local Government Act 1995 can and do stop amalgamations, and have done so as recently as 2015 . But the outcome is never a certainty and depends on the context. In the smaller local governments, amalgamation proposals have often been defeated, and this is a direct reflection of the relatively small numbers required for a binding outcome. In other cases, mainly in the larger local governments, amalgamations have on occasion proceeded because of the much

Table 2: POLLS ON AMALGAMATION PROPOSALS - Pre 2009 reform initiative

\begin{tabular}{|c|c|c|c|c|c|c|c|c|c|c|}
\hline \multirow{2}{*}{$\begin{array}{l}\text { Local } \\
\text { Government } \\
\text { Area } \\
\text { Requesting } \\
\text { Poll }\end{array}$} & \multirow{2}{*}{$\begin{array}{l}\text { Proposed } \\
\text { Amalgamation } \\
\text { Partner }\end{array}$} & \multirow{2}{*}{$\begin{array}{l}\text { Population } \\
\text { Of Proposed } \\
\text { New Entity }\end{array}$} & \multirow{2}{*}{$\begin{array}{l}\text { Date of } \\
\text { Poll }\end{array}$} & \multicolumn{6}{|c|}{ Voting Data For Local Government Area Requesting Poll } & \multirow[t]{2}{*}{ Outcome } \\
\hline & & & & $\begin{array}{l}\text { Number } \\
\text { of } \\
\text { Electors }\end{array}$ & $\begin{array}{l}\text { Total } \\
\text { Number } \\
\text { Of Votes }\end{array}$ & $\begin{array}{l}\text { Number of } \\
\text { No Votes }\end{array}$ & $\begin{array}{l}\text { Number of } \\
\text { Yes Votes }\end{array}$ & $\begin{array}{l}\text { Percentage } \\
\text { of Electors } \\
\text { Voting }\end{array}$ & $\begin{array}{l}\text { Number of } \\
\text { No Votes as } \\
\text { a Percentage } \\
\text { of the Total } \\
\text { Number of } \\
\text { Votes }\end{array}$ & \\
\hline $\begin{array}{l}\text { Northam } \\
\text { Shire }\end{array}$ & $\begin{array}{l}\text { Northam } \\
\text { Town }\end{array}$ & 10,100 & $\begin{array}{l}28 \text { April } \\
2007\end{array}$ & 2,539 & 596 & 555 & 41 & $\begin{array}{l}23 \% \\
\text { Invalid poll }\end{array}$ & $93 \%$ & $\begin{array}{l}\text { Amalgamation } \\
\text { proceeded }\end{array}$ \\
\hline $\begin{array}{l}\text { Greenough } \\
\text { Shire }\end{array}$ & Geraldton City & 33,565 & $\begin{array}{l}2 \\
\text { December } \\
2006\end{array}$ & 8,931 & 2,564 & 2,045 & 519 & $\begin{array}{l}29 \% \\
\text { Invalid poll }\end{array}$ & $80 \%$ & $\begin{array}{l}\text { Amalgamation } \\
\text { proceeded }\end{array}$ \\
\hline $\begin{array}{l}\text { Narrogin } \\
\text { Shire }\end{array}$ & Narrogin Town & 5,436 & $\begin{array}{l}26 \\
\text { February } \\
2004\end{array}$ & 596 & 454 & 325 & 129 & $\begin{array}{l}76 \% \\
\text { Valid poll }\end{array}$ & $72 \%$ & $\begin{array}{l}\text { Amalgamation } \\
\text { defeated }\end{array}$ \\
\hline $\begin{array}{l}\text { Narrogin } \\
\text { Shire }\end{array}$ & Narrogin Town & 5,565 & $\begin{array}{l}17 \text { March } \\
1999\end{array}$ & 619 & 551 & 502 & 49 & $\begin{array}{l}89 \% \\
\text { Valid poll }\end{array}$ & $91 \%$ & $\begin{array}{l}\text { Amalgamation } \\
\text { defeated }\end{array}$ \\
\hline $\begin{array}{l}\text { Greenough } \\
\text { Shire }\end{array}$ & Geraldton City & 31,763 & $\begin{array}{l}20 \\
\text { February } \\
1999\end{array}$ & 7,763 & 4,891 & 4,410 & 479 & $\begin{array}{l}63 \% \\
\text { Valid poll }\end{array}$ & $90 \%$ & $\begin{array}{l}\text { Amalgamation } \\
\text { defeated }\end{array}$ \\
\hline $\begin{array}{l}\text { Northam } \\
\text { Shire }\end{array}$ & $\begin{array}{l}\text { Northam } \\
\text { Town }\end{array}$ & 9,948 & $\begin{array}{l}20 \\
\text { February } \\
1999\end{array}$ & 2,270 & 1,680 & 1,591 & 89 & $\begin{array}{l}74 \% \\
\text { Valid poll }\end{array}$ & $95 \%$ & $\begin{array}{l}\text { Amalgamation } \\
\text { defeated }\end{array}$ \\
\hline $\begin{array}{l}\text { Albany } \\
\text { Shire }\end{array}$ & Albany Town & 28,668 & $\begin{array}{l}28 \\
\text { February } \\
1998\end{array}$ & 9,114 & 3,983 & 1,713 & 2,267 & $\begin{array}{l}43.7 \% \\
\text { Invalid poll }\end{array}$ & $57 \%$ & $\begin{array}{l}\text { Amalgamation } \\
\text { proceeded }\end{array}$ \\
\hline $\begin{array}{l}\text { Albany } \\
\text { Shire }\end{array}$ & $\begin{array}{l}\text { Annexation of } \\
\text { the southern } \\
\text { portions of } \\
\text { the Shires of } \\
\text { Jerramungup } \\
\text { and } \\
\text { Gnowangerup } \\
\text { to the Shire of } \\
\text { Albany }\end{array}$ & $\begin{array}{l}\text { No data } \\
\text { currently } \\
\text { available }\end{array}$ & $\begin{array}{l}6 \text { May } \\
1989\end{array}$ & $\begin{array}{l}\text { No data } \\
\text { currently } \\
\text { available }\end{array}$ & $\begin{array}{l}\text { No data } \\
\text { currently } \\
\text { available }\end{array}$ & $\begin{array}{l}\text { No data } \\
\text { currently } \\
\text { available }\end{array}$ & $\begin{array}{l}\text { No data } \\
\text { currently } \\
\text { available }\end{array}$ & $\begin{array}{l}\text { Less than } \\
33 \% \\
\text { Invalid poll }\end{array}$ & $75 \%$ & $\begin{array}{l}\text { Annexation } \\
\text { defeated }\end{array}$ \\
\hline
\end{tabular}


Table 3: POLLS ON AMALGAMATION PROPOSALS State-wide Reform 2009 -2013

\begin{tabular}{|c|c|c|c|c|c|c|c|c|c|c|}
\hline \multirow{2}{*}{$\begin{array}{l}\text { Local } \\
\text { Government } \\
\text { Area } \\
\text { Requesting } \\
\text { Poll }\end{array}$} & \multirow{2}{*}{$\begin{array}{l}\text { Proposed } \\
\text { Amalgamation } \\
\text { Partner }\end{array}$} & \multirow{2}{*}{$\begin{array}{l}\text { Population } \\
\text { Of Proposed } \\
\text { New Entity }\end{array}$} & \multirow{2}{*}{$\begin{array}{l}\text { Date Of } \\
\text { Poll }\end{array}$} & \multicolumn{6}{|c|}{ Voting Data For Local Government Area Requesting Poll } & \multirow[t]{2}{*}{ Outcome } \\
\hline & & & & $\begin{array}{l}\text { Number of } \\
\text { electors }\end{array}$ & $\begin{array}{c}\text { Total } \\
\text { number of } \\
\text { votes }\end{array}$ & $\begin{array}{l}\text { Number of } \\
\text { No votes }\end{array}$ & $\begin{array}{l}\text { Number of } \\
\text { Yes votes }\end{array}$ & $\begin{array}{l}\text { Percentage } \\
\text { of electors } \\
\text { voting }\end{array}$ & $\begin{array}{c}\text { Number of No votes } \\
\text { as a percentage of } \\
\text { the total number of } \\
\text { votes }\end{array}$ & \\
\hline Cuballing & $\begin{array}{l}\text { Narrogin Shire } \\
\text { Narrogin Town }\end{array}$ & 6,138 & $\begin{array}{l}13 \text { April } \\
2013\end{array}$ & 559 & 449 & 353 & 96 & $\begin{array}{c}80 \% \\
\text { Valid poll }\end{array}$ & $79 \%$ & $\begin{array}{l}\text { Amalgamation } \\
\text { defeated }\end{array}$ \\
\hline Westonia & Yilgarn & 2,015 & $\begin{array}{l}14 \text { April } \\
2012\end{array}$ & 200 & 154 & 126 & 28 & $\begin{array}{c}77 \% \text { - } \\
\text { Valid poll }\end{array}$ & $82 \%$ & $\begin{array}{l}\text { Amalgamation } \\
\text { defeated }\end{array}$ \\
\hline $\begin{array}{l}\text { Geraldton- } \\
\text { Greenough }\end{array}$ & Mullewa & 38,773 & $\begin{array}{l}16 \text { April } \\
2011\end{array}$ & 22,128 & 7,903 & 5721 & 2,158 & $\begin{array}{c}36 \% \\
\text { Invalid poll }\end{array}$ & $72 \%$ & $\begin{array}{l}\text { Amalgamation } \\
\text { proceeded }\end{array}$ \\
\hline Mullewa & $\begin{array}{l}\text { Geraldton- } \\
\text { Greenough }\end{array}$ & 38,773 & $\begin{array}{l}16 \text { April } \\
2011\end{array}$ & 471 & 167 & 139 & 28 & $\begin{array}{c}35 \% \\
\text { Invalid poll }\end{array}$ & $83 \%$ & $\begin{array}{l}\text { Amalgamation } \\
\text { proceeded }\end{array}$ \\
\hline Perenjori & $\begin{array}{l}\text { Mingenew } \\
\text { Morawa } \\
\text { Three Springs }\end{array}$ & 2,607 & $\begin{array}{l}16 \text { April } \\
2011\end{array}$ & 368 & 296 & 273 & 20 & $\begin{array}{c}80 \% \\
\text { Valid poll }\end{array}$ & $92 \%$ & $\begin{array}{l}\text { Amalgamation } \\
\text { defeated }\end{array}$ \\
\hline
\end{tabular}

Table 4: POLLS ON AMALGAMATION PROPOSALS Phase 3: Metropolitan reform 2013-2015

\begin{tabular}{|c|c|c|c|c|c|c|c|c|c|c|}
\hline \multirow{2}{*}{$\begin{array}{l}\text { Local } \\
\text { Government } \\
\text { Area } \\
\text { Requesting } \\
\text { Poll }\end{array}$} & \multirow{2}{*}{$\begin{array}{l}\text { Proposed } \\
\text { Amalgamation } \\
\text { Partner }\end{array}$} & \multirow{2}{*}{$\begin{array}{l}\text { Population } \\
\text { Of Proposed } \\
\text { New Entity }\end{array}$} & \multirow{2}{*}{$\begin{array}{l}\text { Date of } \\
\text { Poll }\end{array}$} & \multicolumn{6}{|c|}{ Voting Data For Local Government Area Requesting Poll } & \multirow[t]{2}{*}{ Outcome } \\
\hline & & & & $\begin{array}{l}\text { Number } \\
\text { Of } \\
\text { Electors }\end{array}$ & $\begin{array}{l}\text { Total } \\
\text { Number } \\
\text { Of Votes }\end{array}$ & $\begin{array}{l}\text { Number Of } \\
\text { No Votes }\end{array}$ & $\begin{array}{l}\text { Number } \\
\text { Of Yes } \\
\text { Votes }\end{array}$ & $\begin{array}{l}\text { Percentage } \\
\text { Of Electors } \\
\text { Voting }\end{array}$ & $\begin{array}{l}\text { Number Of } \\
\text { No Votes As } \\
\text { A Percentage } \\
\text { Of The Total } \\
\text { Number Of } \\
\text { Votes }\end{array}$ & \\
\hline $\begin{array}{l}\text { East } \\
\text { Fremantle }\end{array}$ & Fremantle & & $\begin{array}{l}7 \text { February } \\
2015\end{array}$ & 5,178 & 2825 & 2145 & 680 & $54.7 \%$ & $76 \%$ & $\begin{array}{l}\text { Amalgamation } \\
\text { defeated }\end{array}$ \\
\hline Cockburn & Kwinana & & $\begin{array}{l}7 \text { February } \\
2015\end{array}$ & 61,888 & 22,398 & 18,654 & 3744 & $36.3 \%$ & $83 \%$ & $\begin{array}{l}\text { Amalgamation } \\
\text { defeated (by } \\
\text { Kwinana result) }\end{array}$ \\
\hline Kwinana & Cockburn & & $\begin{array}{l}7 \text { February } \\
2015\end{array}$ & 18,209 & 9618 & 8462 & 1156 & $52.9 \%$ & $88 \%$ & $\begin{array}{l}\text { Amalgamation } \\
\text { defeated }\end{array}$ \\
\hline $\begin{array}{l}\text { South } \\
\text { Perth }\end{array}$ & $\begin{array}{l}\text { Victoria } \\
\text { Park }\end{array}$ & & $\begin{array}{l}7 \\
\text { February } \\
2015\end{array}$ & 26,789 & 13,598 & 10,572 & 3026 & $50.8 \%$ & $78 \%$ & $\begin{array}{l}\text { Amalgamation } \\
\text { defeated }\end{array}$ \\
\hline $\begin{array}{l}\text { Victoria } \\
\text { Park }\end{array}$ & South Perth & & $\begin{array}{l}7 \\
\text { February } \\
2015\end{array}$ & 20,136 & 7627 & 4697 & 2930 & $38.0 \%$ & $62 \%$ & $\begin{array}{l}\text { Amalgamation } \\
\text { defeated (by } \\
\text { South Perth } \\
\text { result) }\end{array}$ \\
\hline
\end{tabular}

larger number of voters required to turn out. The metropolitan reform polls of 2015 showed, however, that it was possible to get binding 'no' votes in more populous local governments.

The Dadour poll provisions still exist within the state's Local Government Act, albeit in their amended, 1995 form. In a final irony, the Crawley Corridor, that part of the City of Subiaco that Tom Dadour had sought to protect when introducing these poll provisions, was transferred to the City of Perth from 1 July 2016 through the City of Perth Act 2016, thus becoming the one and only boundary change that the state government achieved after years of promoting metropolitan reform.

\section{Postscript}

Berry highlights the damage that can be done as a result of poorly thought-through 
legislation. New Zealand councils are currently facing the fourth major change to their core legislation in the last eight years. The changes, which intend to restore binding referenda for consolidation of political or legal boundaries, exempt any consolidation of council services, and are as a result highly contentious. ${ }^{7}$ At the time of writing efforts are underway to find a middle ground between the government's desire to achieve economies of scale by joining services together and local governments' desires to ensure such decisions are made with the agreement of citizens. Mike Reid and Michael Macaulay, Guest Editors

\footnotetext{
Amalgamations may be proposed by the minister, local governments or affected electors, and are subject to an inquiry and recommendation to the minister by the Local
}

Government Advisory Board (Local Government Act 1995, schedule 2.1).

2 While many amendments to local government legislation can be attributed to particular individuals or councils, the Dadour provisions are perhaps the most famous in Western Australia.

3 Note that the Town and Shire of Albany amalgamated on 1 July 1998 to form the City of Albany.

4 Geraldton Guardian, 3 Feb. 1999, p.11; 1 Feb., p. 9; 27 Jan., p.12; 1 Feb., p.11.

5 Ibid., 22 Feb. 1999, p.1; 10 April 2000, p.1.

6 The City of Perth Act came into effect on 1 July 2016

7 The proposal is for any polls to require a majority of residents in all affected councils to support a reorganisation. The traditional approach has been for separate polls to be held in each district and that a reorganisation will only occur where each district votes in support, not a majority of the total.

\section{References}

ACE (2016) 'Direct democracy: referendums', Electoral Knowledge Network, http://aceproject.org/ace-en/focus/direct-democracy/ referendums, accessed 6 July 2016.

Berry (2012) 'Regional transition groups and regional collaborative groups: a voluntary approach to structural reform in Western Australia', Commonwealth Journal of Local Governance, 10, December 2011-June 2012, pp.159-64

Department of Local Government (1976) Annual Report 1976, Government of Western Australia

Department of Local Government (1987) Annual Report 1987, Government of Western Australia

Department of Local Government (1992) The Amalgamation of the Kalgoorlie and Boulder Councils: a history and guidance for the future, July, Government of Western Australia

Department of Local Government (1996) Annual Report 1996, Government of Western Australia

Department of Local Government (2010) Reform Case Studies: amalgamation in Western Australia: City of Geraldton-Greenough Shire of Northam, May, West Perth: Government of Western Australia Department of Local Government and Communities (2016) 'Local government reform', https://www.dlgc.wa.gov.au/CommunityInitiatives/ Pages/Local-Government-Reform.aspx/Page.aspx, accessed 6 August, 2013.

Legislative Assembly of Western Australia (1975) Hansard, 29 April, http://www.parliament.wa.gov.au/Hansard/hansard1870to1995.nsf/ vwMainBackground/19750429_Assembly.pdf/\$File/19750429_ Assembly.pdf
Legislative Assembly of Western Australia (1998) Hansard, 22 October, http://www. parliament.wa.gov.au/Hansard/HANS35.NSF/NFS/b2a6a3f b8d49a102482566aa00125b4c?OpenDocument

Legislative Assembly of Western Australia (2013) Hansard, 18 September, http://www.parliament.wa.gov.au/Hansard/hansard. nsf/0/58041d5862eed80a48257bec002a3374/\$FILE/ A39+S1+20130918+p4365b-4394a.pdf

Legislative Assembly of Western Australia (2014) Hansard, 26 November, http://www. parliament.wa.gov.au/Hansard/hansard.nsf/0/b5e8e9b8a3 3e1f8048257dc8000d93d9/\$FILE/A39+S1+20141126+p8879b8894a.pdf

Office of the Minister for Local Government (2011) 'Birth of City of Greater Geraldton', media release, 1 July, https://www. mediastatements.wa.gov.au/Pages/Barnett/2011/07/Birth-of-City-ofGreater-Geraldton.aspx, accessed 6 July 2016

Offices of the Premier and Minister for Local Government (2015) 'Future of LG reform now rests with councils', media release, 17 February, https://www.mediastatements.wa.gov.au/Pages/Barnett/2015/02/ Future-of-LG-reform-now-rests-with-councils--.aspx, accessed 18 July 2016

Spillman, K. (1985) Identity Prized: a history of Subiaco, Nedlands, WA: UWA Publishing

Wikipedia (2016) 'Popular referenda', Wikipedia, https://en.wikipedia.org/ wiki/Popular_referendum, accessed 6 July 2016

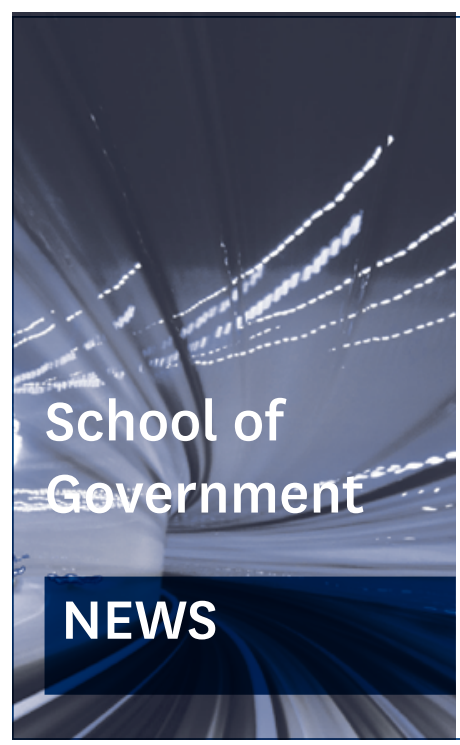

\section{MeGov courses stimulate collaboration with the University of Indonesia}

The School of Government received a week-long visit in November by Dr Roy Salomo and Zuliansyah Zulkarnain (Ichan) from the University of Indonesia to discuss collaboration, specifically about establishing a double Master's degree in e-Government between VUW and UI, Indonesia's leading university. This visit followed an earlier visit from $\mathrm{UI}$ in 2015. E-government is one of several capabilities that Indonesia is promoting in its government reforms. Highly successful meetings were held with a range of staff, other VuW offices and external stakeholders, increasing understanding and agreement around a possible curriculum. VUW's Master's in e-Government started in 2013 and is an innovative degree of which there are only few in the world. 